\title{
The Effect of Added Ligands on the Reactions of [Ni(COD)(dppf)] with Alkyl Halides: Halide Abstraction May Be Reversible
}

\author{
Megan E. Greaves, Thomas O. Ronson, Feliu Maseras, and David J. Nelson* \\ Cite This: https://doi.org/10.1021/acs.organomet.1c00280 \\ Read Online
}

ACCESS

Llll Metrics \& More

Article Recommendations

Supporting Information

ABSTRACT: The reactions of dppf-nickel(0) with alkyl halides proceed via three-coordinate nickel $(0)$ intermediates of the form $[\mathrm{Ni}(\mathrm{dppf})(\mathrm{L})]$. The effects of the identity of the added ligand (L) on catalyst speciation and the rates of reactions of $[\mathrm{Ni}(\mathrm{COD})(\mathrm{dppf})]$ with alkyl halides have been investigated using kinetic experiments and density functional theory calculations. A series of monodentate ligands have been investigated in attempts to identify trends in reactivity. Sterically bulky and electrondonating ligands are found to decrease the reaction rate. It was found that (i) the halide abstraction step is not always irreversible and the subsequent

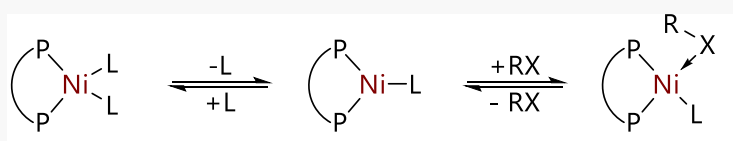
Which ligand $(L)$ is best? recombination of a nickel(I) complex with an alkyl halide can have a significant effect on the overall rate of the reaction and (ii) some ligands lead to very stable $\left[\mathrm{Ni}(\mathrm{dppf})(\mathrm{L})_{2}\right]$ species. The yields of prototypical (dppf)nickel-catalyzed Kumada cross-coupling reactions of alkyl halides are significantly improved by the addition of free ligands, which provides another important variable to consider when optimizing nickel-catalyzed reactions of alkyl halides.

\section{INTRODUCTION}

The importance of molecules that contain a large number of $\mathrm{sp}^{3}$ centers in industries such as pharmaceuticals and agrochemicals is driving much of the reaction discovery and development in the field of nickel catalysis. ${ }^{1,2}$ However, despite recent advances in our mechanistic understanding of nickel catalysis, ${ }^{3,4}$ gaps in this understanding still remain. This is apparent for the case of the reactions of nickel $(0)$ complexes with alkyl halides, which are quite different from the reactions of nickel( 0$)$ complexes with $\mathrm{sp}^{2}$ organohalides. ${ }^{5}$ The reactions of alkyl halides have a greater propensity to involve radical intermediates, and deleterious $\beta$ hydride elimination presents further challenges. We have recently focused our attention on the reactions of alkyl halides with nickel(0), with the aim of developing a better understanding of these reactions and thereby underpinning future reaction discovery, development, and understanding.

The outcomes of nickel-catalyzed reactions can be extremely sensitive to the structure(s) of the ligand(s). For example, Liu et al. found that $\left[\mathrm{Ni}(\mathrm{COD})_{2}\right] / \mathrm{dppf}$ was not a competent catalyst for the cross-coupling of phenyl triflate and aniline but that a modified ligand (1,1'-bis(di(3,5-trifluoromethylphenyl)phosphino)ferrocene) enabled the reaction to achieve almost quantitative conversion. ${ }^{6}$ There are many examples of situations where the mechanisms of nickel-catalyzed reactions can also be very sensitive to the ligand structure. If the nickel-catalyzed Suzuki-Miyaura coupling of benzylic esters is carried out using tricyclohexylphosphine as the ligand, the stereochemistry at the benzylic position is retained; however, the use of SIMes produces the stereoinverted product via a different mechanistic pathway. ${ }^{7}$ The size of the $\mathrm{NHC}$ ligand in $\left[\mathrm{Ni}(\mathrm{NHC})_{2}\right]$ complexes determines whether $\left[\mathrm{Ni}(\mathrm{Ar}) \mathrm{X}(\mathrm{NHC})_{2}\right]$ or $[\mathrm{NiX}$ -
$\left.(\mathrm{NHC})_{2}\right]$ products result from their reactions with aryl halides. ${ }^{8,9}$ The choice of ligand type-bisphosphine or bipyridine-is crucial in the trifluoromethylthiolation reactions of aryl halides. ${ }^{10}$ Changes in the phosphine ligand structure can influence oxidative addition selectivity in the reactions of esters $^{11}$ or change oxidative addition chemoselectivity entirely. $^{12}$

The reactions of alkyl halides with nickel(0) have received relatively little attention compared to reactions of aryl halides and other aryl electrophiles. ${ }^{13-17}$ Baird has studied the reactions of various alkyl halides with $\left[\mathrm{Ni}\left(\mathrm{PPh}_{3}\right)_{4}\right]$ via variable temperature ${ }^{1} \mathrm{H}$ and ${ }^{31} \mathrm{P}$ NMR spectroscopic analyses of reactions in situ. ${ }^{18}$ The major products from the reactions of iodoalkanes are alkanes and alkenes, with a nickel hydride species obtained as a minor product; this suggests that formal oxidative addition was followed by $\beta$-hydride elimination. The alkanes were proposed to arise from the generation of alkyl radicals by halide abstraction, which then abstract the hydride ligand from a nickel hydride complex. The trends observed in the reactivity of alkyl halides followed the stability of the corresponding radicals, consistent with an operative radical mechanism.

We recently published a detailed study of the reactions of the model complex $[\mathrm{Ni}(\mathrm{COD})(\mathrm{dppf})]^{19}$ (1) with alkyl halides. ${ }^{20}$

Received: May 6, 2021 
The experimental and computational evidence that was gathered supported a mechanism in which $[\mathrm{Ni}(\mathrm{COD})(\mathrm{dppf})]$ was in equilibrium with $\left[\mathrm{Ni}(\mathrm{dppf})_{2}\right]$ (2) (with the additional dppf being a trace impurity in $\mathbf{1})$, and $\left[\mathrm{Ni}\left(\kappa^{2}-\mathrm{dppf}\right)\left(\kappa^{1}-\mathrm{dppf}\right)\right]$ performed a halide abstraction step to produce $\left[\mathrm{Ni}(\mathrm{X})\left(\kappa^{2}\right.\right.$ dppf $)\left(\kappa^{1}\right.$-dppf)] plus an alkyl radical (Scheme 1a); subsequent

Scheme 1. (a) Our Previous Study of the Reactions of [Ni(COD)(dppf)] with Alkyl Halides, and (b) This Work

(a) Reactions of alkyl halides with [Ni(COD)(dppf)] (previous work)

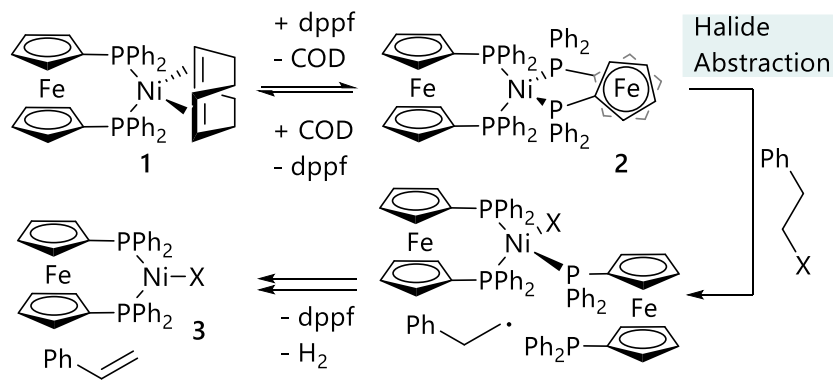

(b) Effect of ligand additives on kinetics (this work)

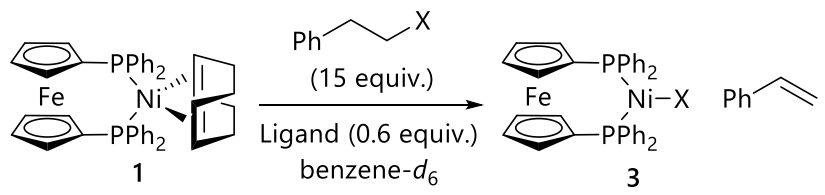

dppf dissociation and the recombination of the alkyl radical and nickel(I) complex yielded the formal oxidative addition product $[\mathrm{Ni}(\mathrm{X})(\mathrm{R})(\mathrm{dppf})]$, which underwent rapid $\beta$-hydride elimination. The final products were $[\mathrm{Ni}(\mathrm{X})(\mathrm{dppf})](3)$ and alkene, with no alkane product observed.

The reaction of $[\mathrm{Ni}(\mathrm{COD})(\mathrm{dppf})]$ with alkyl halides relies upon the presence of additional dppf in order to form the threecoordinate species necessary for the halide abstraction step. However, the bidentate nature of $\mathrm{dppf}$ means that $\left[\mathrm{Ni}(\mathrm{dppf})_{2}\right]$ is lower in energy than the desired $\left[\mathrm{Ni}\left(\kappa^{2}-\mathrm{dppf}\right)\left(\kappa^{1}\right.\right.$-dppf $\left.)\right]$ intermediate. Here, we have examined the use of a range of alternative monodentate ligands and their effects on the rate of stoichiometric and catalytic reactions of alkyl halides (Scheme 1b).

\section{RESULTS AND DISCUSSION}

Kinetic Studies of Stoichiometric Reactions with Alternative Ligands. Our previous study ${ }^{20}$ established that the rate of reaction between $[\mathrm{Ni}(\mathrm{COD})(\mathrm{dppf})](\mathbf{1})$ and alkyl halides was significantly increased by the addition of free dppf ligands, as this shifted the equilibrium between $\mathbf{1}$ and $\left[\mathrm{Ni}(\mathrm{dppf})_{2}\right]$ toward the latter species. For this study, a selection of monodentate group 15 ligands were assembled with a diverse range of steric and electronic properties and where the Lewis basic atom was nitrogen, phosphorus, arsenic, or antimony. These were all used as additives in stoichiometric reactions between 1 and (2-bromoethyl)benzene (4-Br) which were monitored by ${ }^{31} \mathrm{P}$ NMR spectroscopy. All experiments were pseudo-first-order in $\mathbf{1}$, and the ${ }^{31} \mathrm{P}$ NMR spectra confirmed that dppf remained bound to the nickel center throughout, with no free dppf ligand detected $\left(\delta_{\mathrm{P}}=-17 \mathrm{ppm}\right)$. Data were collected at one or two of three temperatures $(263,273$, or $293 \mathrm{~K}$ ) depending on how fast the reaction proceeded; the results for reactions with 15 monodentate ligands, along with previous data for the reaction with added dppf, ${ }^{20}$ are recorded in Scheme 2. Pseudo-first-order constants are listed in the order of largest to smallest. Data span a ca. 200-fold range of rate constants.

Scheme 2. Kinetic Studies of the Reactions between $[\mathrm{Ni}(\mathrm{COD})(\mathrm{Dppf})]$ (1) $\left(0.022 \mathrm{~mol} \mathrm{~L}^{-1}\right)$ and (2Bromoethyl)benzene (4-Br) $\left(0.33 \mathrm{~mol} \mathrm{~L}^{-1}\right)$ in Toluene- $d_{8}$ in the Presence of Various Added Ligands $\left(0.0132 \mathrm{~mol} \mathrm{~L}^{-1}\right)$

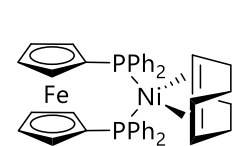

1

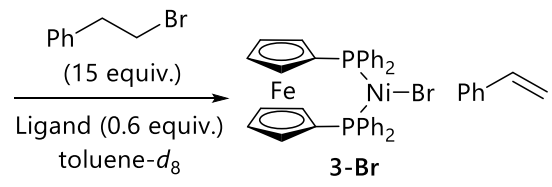

\begin{tabular}{|c|c|c|c|c|}
\hline \multirow{2}{*}{ Ligand } & \multicolumn{4}{|c|}{$k_{o b s} \times 10^{3} \mathrm{~s}^{-1}$} \\
\hline & $263 \mathrm{~K}$ & $273 \mathrm{~K}$ & $293 \mathrm{~K}$ & $k_{\text {rel }}$ \\
\hline $\mathrm{P}\left(p-\mathrm{C}_{6} \mathrm{H}_{4} \mathrm{CF}_{3}\right)_{3}$ & $2.8(1)$ & & & 1.00 \\
\hline $\mathrm{P}\left(m-\mathrm{C}_{6} \mathrm{H}_{4} \mathrm{Me}\right)_{3}$ & $2.4(1)$ & & & 0.89 \\
\hline $\mathrm{P}\left(p-\mathrm{C}_{6} \mathrm{H}_{4} \mathrm{~F}\right)_{3}$ & $2.4(1)$ & & & 0.89 \\
\hline $\mathrm{P}\left(p-\mathrm{C}_{6} \mathrm{H}_{4} \mathrm{Me}\right)_{3}$ & $1.7(1)$ & & & 0.63 \\
\hline $\mathrm{PPh}_{3}$ & $1.40(3)$ & & & 0.52 \\
\hline $\mathrm{P}\left(p-\mathrm{C}_{6} \mathrm{H}_{4} \mathrm{OMe}\right)_{3}$ & $1.3(1)$ & $4.4(1)$ & & 0.48 \\
\hline $\mathrm{FcPPh}_{2}$ & & $1.80(6)$ & & 0.20 \\
\hline $\mathrm{P}(n-\mathrm{Bu})_{3}$ & & $0.87(1)$ & & 0.091 \\
\hline dppf & & $0.50(1)$ & & 0.055 \\
\hline $\mathrm{PMe}_{3}$ & & & $3.3(1)$ & 0.030 \\
\hline $\mathrm{AsPh}_{3}$ & & & $2.7(1)$ & 0.026 \\
\hline $\mathrm{SbPh}_{3}$ & & & $1.8(1)$ & 0.019 \\
\hline $\mathrm{PCy}_{3}$ & & & $0.94(3)$ & 0.008 \\
\hline $\mathrm{P}\left(o-\mathrm{C}_{6} \mathrm{H}_{4} \mathrm{Me}\right)_{3}$ & & $0.04(1)$ & $0.49(2)$ & 0.004 \\
\hline $\mathrm{P}(\mathrm{OPh})_{3}$ & & & $0.45(2)$ & 0.004 \\
\hline $\mathrm{NEt}_{3}$ & & & $0.45(2)$ & 0.004 \\
\hline
\end{tabular}

A series of reactions were carried out with different concentrations of triphenylphosphine, confirming that the reaction is first order in added triphenylphosphine (Figure 1a,b); our previous work noted that the reaction was first order in dppf when this was the added ligand. ${ }^{20}$

The use of diphenylphosphinoferrocene $\left(\mathrm{FcPPh}_{2}\right)$ as an additive led to a higher rate of reaction than the corresponding experiment with dppf. This can be rationalized by considering the requirement for (bidentate) dppf to dissociate one phosphine atom from the nickel center to enable the reaction to occur; the binding of a second $\mathrm{FcPPh}_{2}$ ligand does not benefit from the chelate effect.

It is apparent that neither the steric nor the electronic properties of the ligand dominate the observed effects on reaction rates; The Tolman electronic parameter (TEP) and cone angle data are gathered for some of the ligands deployed in this study (Table 1). ${ }^{21}$ It was initially anticipated that electronrich ligands would generate a more reactive nickel( 0$)$ complex and therefore accelerate halide abstraction. However, the use of tricyclohexylphosphine leads to a very slow reaction with no conversion after $45 \mathrm{~min}$ at $273 \mathrm{~K}\left(k_{r e l}=0.008\right)$; reactions in the presence of trimethylphosphine $\left(k_{r e l}=0.030\right)$ or tri $(n$-butyl $)$ phosphine $\left(k_{r e l}=0.091\right)$ are faster. The reaction with triphenylphosphine as an additive led to a reaction that was faster still $\left(k_{r e l}=0.52\right)$, despite being less electron-rich. 

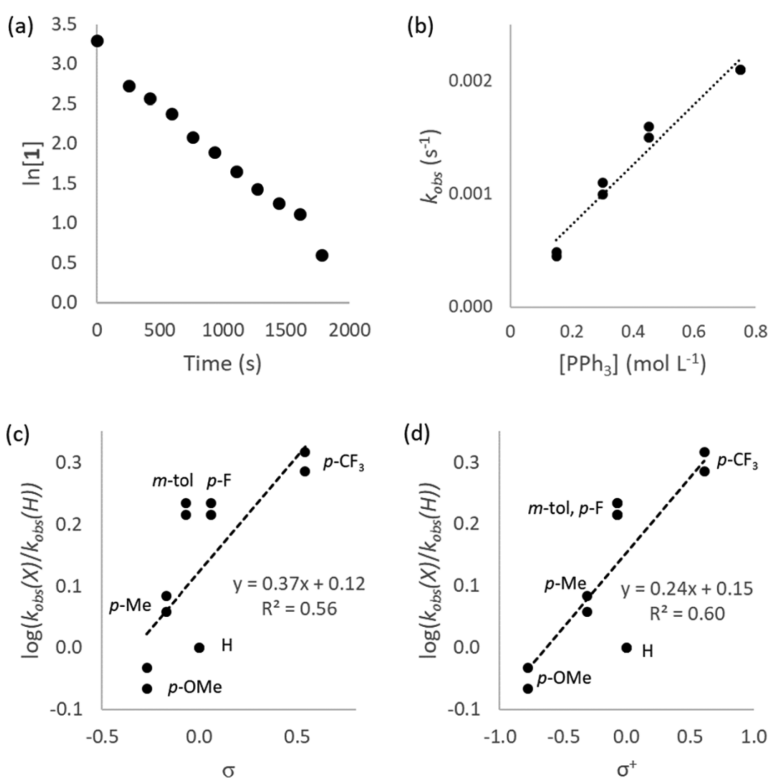

Figure 1. (a) Kinetic data for the reaction between [Ni(COD) (dppf)] (1) $\left(0.022 \mathrm{~mol} \mathrm{~L}^{-1}\right)$ and (2-bromoethyl)benzene (4-Br) $(0.33 \mathrm{~mol}$ $\left.\mathrm{L}^{-1}\right)$ at $263 \mathrm{~K}$ in toluene- $d_{8}$ in the presence of triphenylphosphine $\left(0.0132 \mathrm{~mol} \mathrm{~L}^{-1}\right)$. (b) Plot of $k_{\text {obs }}$ versus $\left[\mathrm{PPh}_{3}\right]$. (c) Hammett plot (using substituent constants $\sigma$ ) for the reactions in the presence of substituted triarylphosphines. (d) Hammett plot (using substituent constants $\sigma^{+}$).

Table 1. Relative Rate Constants for Selected Reactions where the TEP and Cone Angle Are Known ${ }^{21}$ for the Corresponding Ligand

\begin{tabular}{lcccc}
\multicolumn{1}{c}{ ligand } & TEP $\left(\mathrm{cm}^{-1}\right)$ & cone angle $\left(^{\circ}\right)$ & $\% V_{\text {bur }}$ & $k_{\text {rel }}$ \\
$\mathrm{P}\left(m-\mathrm{C}_{6} \mathrm{H}_{4} \mathrm{Me}\right)_{3}$ & 2067.2 & & & 0.89 \\
$\mathrm{P}\left(p-\mathrm{C}_{6} \mathrm{H}_{4} \mathrm{~F}\right)_{3}$ & 2071.3 & & 31.4 & 0.89 \\
$\mathrm{P}\left(p-\mathrm{C}_{6} \mathrm{H}_{4} \mathrm{Me}\right)_{3}$ & 2066.7 & 145 & 31.3 & 0.63 \\
$\mathrm{PPh}_{3}$ & 2068.9 & 145 & 31.2 & 0.52 \\
$\mathrm{P}\left(p-\mathrm{C}_{6} \mathrm{H}_{4} \mathrm{OMe}\right)_{3}$ & 2066.7 & & 31.3 & 0.48 \\
$\mathrm{P}(n-\mathrm{Bu})_{3}$ & 2060.3 & 132 & & 0.091 \\
$\mathrm{PMe}$ & 2064.1 & 118 & 24.0 & 0.030 \\
$\mathrm{PC} y_{3}$ & 2056.4 & 170 & 31.9 & 0.008 \\
$\mathrm{P}\left(o-\mathrm{C}_{6} \mathrm{H}_{4} \mathrm{Me}\right)_{3}$ & 2066.6 & 194 & & 0.004 \\
$\mathrm{P}(\mathrm{OPh})_{3}$ & 2085.3 & 128 & & 0.004 \\
\hline
\end{tabular}

A Hammett $\operatorname{plot}^{22}$ of $\log \left(k_{\mathrm{obs}(\mathrm{X})} / k_{\mathrm{obs}(\mathrm{H})}\right)$ versus $\sigma$ for a set of five triarylphosphines gave a relatively shallow gradient of $\rho=$ 0.37 (Figure 1c). ${ }^{23}$ A slightly better correlation with $\rho=0.24$ is obtained using $\sigma^{+}$parameters for the para-substituted triarylphosphines (Figure 1d), ${ }^{24}$ but in both cases these show that the reaction is promoted by electron-poor triarylphos- phines. The relatively simple reaction mechanism that we had initially anticipated-i.e., ligand binding, halide abstraction, and ligand dissociation-is too simple to explain the observed trends, and so, we turned to computational chemistry for additional insight.

DFT Calculations of the Reaction Mechanism. Density functional theory (DFT) calculations carried out during our earlier study ${ }^{20}$ supported the proposal that the reaction occurs via formation of a three-coordinate nickel $(0)$ complex, halide abstraction to form nickel(I) plus a radical, and recombination of these species to form a nickel(II) complex. The nickel(II) complex is then proposed to undergo $\beta$-hydride elimination followed by comproportionation to form $[\mathrm{NiX}(\mathrm{dppf})]$ (3), styrene, and hydrogen. For details of the level of theory used in this study please see the Experimental Section. Trimethylamine was used as a conformationally less complicated model for triethylamine; we have previously used trimethylphosphine as a model for triethylphosphine. ${ }^{25}$

The reactions of $[\mathrm{Ni}(\mathrm{COD})(\mathrm{dppf})]$ (1) with (2bromoethyl)benzene (4-Br) in the presence of added ligands were systematically studied. Scheme 3 outlines the mechanism, while Table 2 records the corresponding data and the overall barrier for the halide abstraction transition state versus the lowest energy preceding intermediate. For simplicity, the reactions with the corresponding alkyl chloride and alkyl iodide were not studied here.

In most cases, $[\mathrm{Ni}(\mathrm{dppf})(\mathrm{L})]$ had $G_{\text {rel }}=-0.6$ to $1.6 \mathrm{kcal} / \mathrm{mol}$, with the exceptions of trimethylamine $\left(G_{\text {rel }}=14.3 \mathrm{kcal} / \mathrm{mol}\right)$ and triphenylphosphite $\left(G_{\mathrm{rel}}=-6.1 \mathrm{kcal} / \mathrm{mol}\right)$. The strong binding of the $\pi$-accepting phosphite to the dppf-nickel $(0)$ fragment is not unexpected, given the important role of $\pi$ backbonding in the coordination chemistry of organometallic complexes of nickel(0). ${ }^{26-28}$ The steric profile of each coordinated ligand in a selection of the corresponding $[\mathrm{Ni}(\mathrm{dppf})(\mathrm{L})]$ complexes was evaluated using the percent buried volume $\left(\% V_{\text {bur }}\right)$ metric (see the Supporting Information for the full data set). ${ }^{29-31}$ This metric has been widely applied across organometallic chemistry and catalysis. ${ }^{32,33}$ The $\% V_{\text {bur }}$ value did not vary as much as was anticipated. For example, tricyclohexylphosphine and triphenylphosphine have $\% V_{\text {bur }}$ that vary by less than one unit (31.9 and 31.2, respectively), despite their vastly different cone angles $\left(170^{\circ}\right.$ and $145^{\circ}$, respectively). Trimethylphosphine (24.0), triphenylarsine (22.7), and triphenylstibene (27.7) have a lower $\% V_{\text {bur }}$ than triarylphosphines (ca. $31)$ in this environment.

It is possible for two monodentate ligands to coordinate the $[\mathrm{Ni}(\mathrm{dppf})]$ fragment in most cases; $\left[\mathrm{Ni}(\mathrm{dppf})\left(\mathrm{PMe}_{3}\right)_{2}\right]^{34}$ and $\left[\mathrm{Ni}(\mathrm{dppf})\left(\mathrm{P}(\mathrm{OPh})_{3}\right)_{2}\right]^{35}$ are known species that have been fully characterized using methods including single crystal X-ray diffraction. The possible formation of these species was also

Scheme 3. Mechanism for the Reactions of 1 Plus the Added Ligand (L) with (2-Bromoethyl)benzene 4-Br
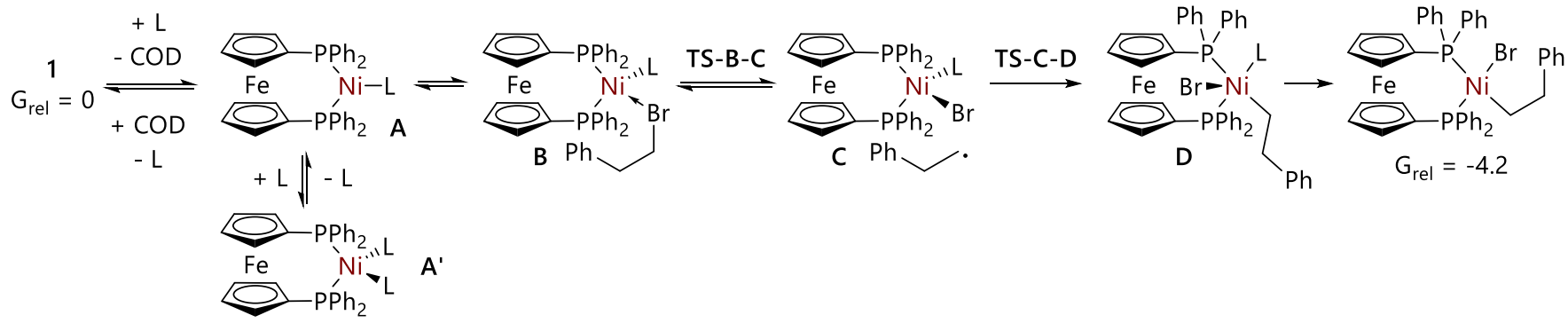
Table 2. Free Energies for the Complexes Considered during This Study, Obtained at the M06/6-311 + G(d,p),LANL2DZ(d,p)[Sb], SMD(Benzene)//B3LYP-D3/6-31G(d),LANL2TZ(f)[Ni,Fe],LANL2DZ(d,p)[Br,As,Sb] Level of Theory, and Quoted Relative to $[\mathrm{Ni}(\mathrm{COD})(\mathrm{dppf})](1)$

\begin{tabular}{|c|c|c|c|c|c|c|c|c|c|c|}
\hline \multirow[b]{2}{*}{ ligand } & \multirow[b]{2}{*}{$k_{\text {rel }}$} & \multicolumn{9}{|c|}{$G_{\text {rel }}(\mathrm{kcal} / \mathrm{mol})$} \\
\hline & & A & $\mathrm{A}^{\prime}$ & B & TS-B-C & $\mathrm{C}$ & TS-C-D & $\mathrm{D}$ & $\Delta G^{\ddagger}(\mathrm{HA})$ & $\Delta G^{\ddagger}$ (recomb. $)$ \\
\hline $\mathrm{P}\left(p-\mathrm{C}_{6} \mathrm{H}_{4} \mathrm{CF}_{3}\right)_{3}$ & 1.00 & 0.0 & 4.1 & 4.3 & 23.8 & 20.5 & & & 23.8 & \\
\hline $\mathrm{P}\left(p-\mathrm{C}_{6} \mathrm{H}_{4} \mathrm{~F}\right)_{3}$ & 0.89 & 1.0 & 2.9 & 2.8 & 22.5 & 4.5 & & & 22.5 & \\
\hline $\mathrm{P}\left(p-\mathrm{C}_{6} \mathrm{H}_{4} \mathrm{Me}\right)_{3}$ & 0.63 & 1.6 & 5.8 & 3.8 & 22.7 & 18.9 & & & 22.7 & \\
\hline $\mathrm{PPh}_{3}$ & 0.52 & 1.4 & 5.3 & 2.5 & 24.6 & 17.7 & 26.4 & 10.8 & 24.6 & 26.4 \\
\hline $\mathrm{P}\left(p-\mathrm{C}_{6} \mathrm{H}_{4} \mathrm{OMe}\right)_{3}$ & 0.48 & 1.0 & 3.2 & 4.2 & 21.4 & 3.5 & & & 21.4 & \\
\hline $\mathrm{FcPPh}_{2}$ & 0.20 & 0.3 & 8.0 & 3.0 & 24.7 & 7.2 & & & 24.7 & \\
\hline dppf & 0.055 & $-0.2^{a}$ & $b$ & 2.9 & 24.6 & 10.1 & & & 26.1 & \\
\hline $\mathrm{PMe}_{3}$ & 0.030 & 0.0 & -12.2 & 5.5 & 22.2 & 5.9 & 4.5 & 4.1 & 34.4 & 16.7 \\
\hline $\mathrm{AsPh}_{3}$ & 0.026 & 1.4 & -5.3 & 12.1 & 22.0 & 9.4 & & & 27.3 & \\
\hline $\mathrm{SbPh}_{3}$ & 0.019 & 0.9 & -14.6 & 9.3 & 19.0 & 11.2 & & & 33.6 & \\
\hline $\mathrm{PCy}_{3}$ & 0.008 & -0.2 & $c$ & 4.5 & 26.3 & -0.2 & 31.7 & 14.6 & 26.3 & 31.9 \\
\hline $\mathrm{P}(\mathrm{OPh})_{3}$ & 0.004 & -6.1 & -21.6 & -3.3 & 18.8 & -13.1 & & & 40.4 & \\
\hline $\mathrm{NMe}_{3}$ & 0.004 & 14.3 & ${ }^{c}$ & 21.1 & 32.8 & 15.1 & & & 32.8 & \\
\hline
\end{tabular}

${ }^{a}\left[\mathrm{Ni}(\mathrm{dppf})_{2}\right]$ has $G_{\text {rel }}=-1.5 \mathrm{kcal} / \mathrm{mol}^{.}{ }^{b}\left[\mathrm{Ni}(\mathrm{dppf})\left(\kappa^{1} \text {-dppf }\right)_{2}\right]$ is unlikely to be competitive with $\left[\mathrm{Ni}(\mathrm{dppf})_{2}\right]$; note that $\left[\mathrm{Ni}(\mathrm{dppf})\left(\mathrm{FcPPh}_{2}\right)_{2}\right]$ has $G_{\text {rel }}=8.0 \mathrm{kcal} / \mathrm{mol}^{c}{ }^{c}$ Attempts to locate structures for $\left[\mathrm{Ni}(\mathrm{dppf})\left(\mathrm{PCy}_{3}\right)_{2}\right]$ and $\left[\mathrm{Ni}(\mathrm{dppf})\left(\mathrm{NMe}_{3}\right)_{2}\right]$ led to spontaneous dissociation of one of the ligands during geometry optimization.

investigated computationally. In the case of trimethylamine and tricyclohexylphosphine, geometry optimization led to the spontaneous decoordination of the second ligand. In all other cases, $\left[\mathrm{Ni}(\mathrm{dppf})(\mathrm{L})_{2}\right]$ complexes could be optimized as minima on the free energy surface. For triphenylarsine, triphenylstibene, trimethylphosphine, and triphenylphosphite the binding of a second ligand is very favorable, and so this increases the barrier to halide abstraction by $[\mathrm{Ni}(\mathrm{dppf})(\mathrm{L})]$; this explains the rather poor performance of these four ligands in the kinetic experiments. The binding of a second diphenylphosphinoferrocene or triarylphosphine ligand is endergonic by a few $\mathrm{kcal} / \mathrm{mol}$.

The next step is the formation of $\left[\mathrm{Ni}\left(\mathrm{BrCH}_{2} \mathrm{CH}_{2} \mathrm{Ph}\right)\right.$ $(\mathrm{dppf})(\mathrm{L})]$, although in many cases the steric environment around nickel precludes short $\mathrm{Ni}$... Br distances. These are typically slightly higher in energy than $[\mathrm{Ni}(\mathrm{dppf})(\mathrm{L})]$, presumably due to the entropic cost of bringing two molecules together. Halide abstraction takes place subsequently, and forms $[\mathrm{NiBr}(\mathrm{dppf})(\mathrm{L})]$ plus an alkyl radical. Our initial treatment of the data assumed facile ligand dissociation and radical recombination to form $\left[\mathrm{NiBr}\left(\mathrm{CH}_{2} \mathrm{CH}_{2} \mathrm{Ph}\right)(\mathrm{dppf})\right](\mathbf{5})\left(G_{\text {rel }}=\right.$ $-4.2 \mathrm{kcal} / \mathrm{mol}$ ) which transpired to be an oversimplification of the reaction mechanism; ${ }^{20}$ the events after halide abstraction but before the formation of $\mathbf{5}$ will be discussed subsequently.

An initial analysis of the data revealed limited agreement between experimentally determined rate constants and computationally determined halide abstraction barriers. $\mathrm{FcPPh}_{2}$ is a more effective ligand than dppf, and this is reflected in the $1.4 \mathrm{kcal} / \mathrm{mol}$ decrease in $\Delta G^{\ddagger}$. However, the DFT data for triarylphosphine ligands are at odds with the experimental observations and instead suggest that the reactions with more electron-rich ligands should proceed more quickly.

We next considered the possibility that the halide abstraction is in fact reversible and that a subsequent step in the mechanism might be rate-determining in some or all cases. Experimental evidence suggests that the alkyl radical exists for long enough to undergo unimolecular rearrangement reactions, but the lack of any corresponding alkane or dimerized product suggests that it is captured by the nickel complex relatively quickly. ${ }^{20}$ However, the radical might be captured by the formation of a nickel(II) complex (formation of a $\mathrm{C}-\mathrm{Ni}$ bond) or by the abstraction of the halide from the nickel center ( $\mathrm{C}-\mathrm{X}$ reformation), especially within the relatively crowded environment of the nickel center.

Further calculations identified transition states for the combination of the alkyl radical with $[\mathrm{NiBr}(\mathrm{dppf})(\mathrm{L})]$, where $\mathrm{L}$ is trimethylphosphine, tricyclohexylphosphine, or triphenylphosphine. In the case of trimethylphosphine, two transition states were characterized: one with approximately trigonal bipyramidal geometry and one (of lower energy) with distorted square-based pyramidal geometry. For tricyclohexylphosphine and triphenylphosphine pathways only the latter geometry of the transition state was located; attempts to locate trigonal bipyramidal transition states were unsuccessful. Geometry optimizations of structures along the reaction coordinate confirmed that the transition states linked the nickel(I) complex and a square-based pyramidal nickel(II) species.

The barrier to recombination varies considerably depending on the identity of the ligand. For tricyclohexylphosphine, the radical capture transition state is significantly higher in energy than the halide abstraction transition state (31.7 versus 26.3 $\mathrm{kcal} / \mathrm{mol}$ ), which explains the poor performance of this ligand in the stoichiometric reactions. In contrast, the recombination of the radical with the trimethylphosphine complex presents no significant barrier.

Figure 2 displays the free energy profiles for the reactions where trimethylphosphine, tricyclohexylphosphine, and triphenylphosphine are used as additives; these illustrate the three types of behavior that are observed in these reactions. These are discussed in turn.

In the case of trimethylphosphine, the formation of $\left[\mathrm{Ni}(\mathrm{dppf})\left(\mathrm{PMe}_{3}\right)_{2}\right]$ inhibits the reaction because one of the trimethylphosphine ligands must dissociate before halide abstraction can occur, and this carries a significant energetic penalty. Similar behavior is observed for triphenylphosphite, triphenylarsine, and triphenylstibene.

The reaction in the presence of tricyclohexylphosphine suffers from a large barrier to radical recombination with the nickel(I) intermediate. A structure for $\left[\mathrm{Ni}(\mathrm{dppf})\left(\mathrm{PCy}_{3}\right)_{2}\right]$ could not be obtained because one of the tricyclohexylphosphine ligands dissociated during geometry optimization, and so, the barrier to halide abstraction is reasonable. However, the radical formed 


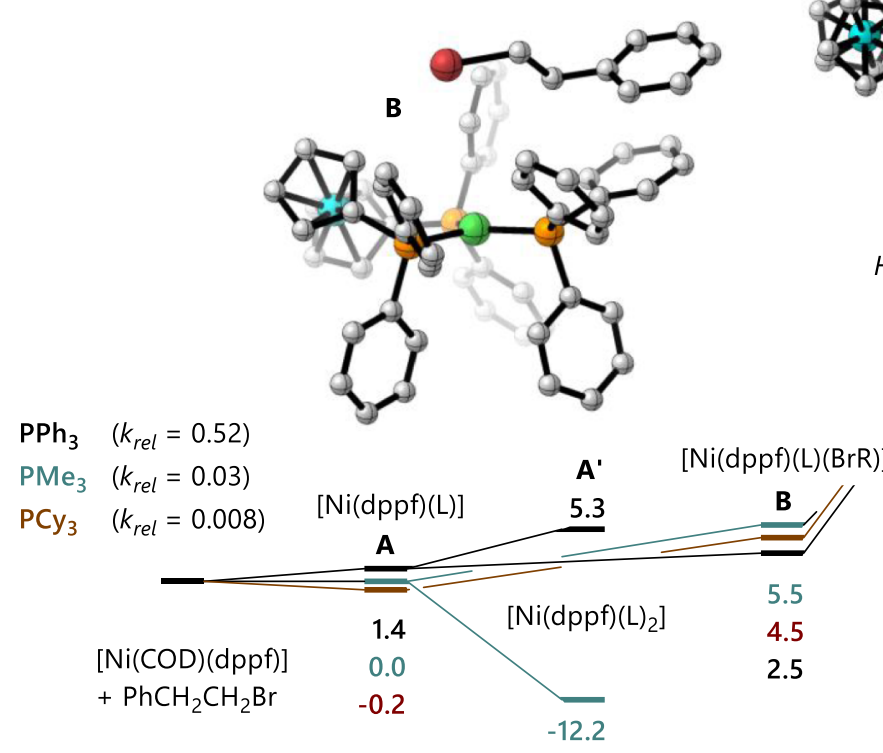

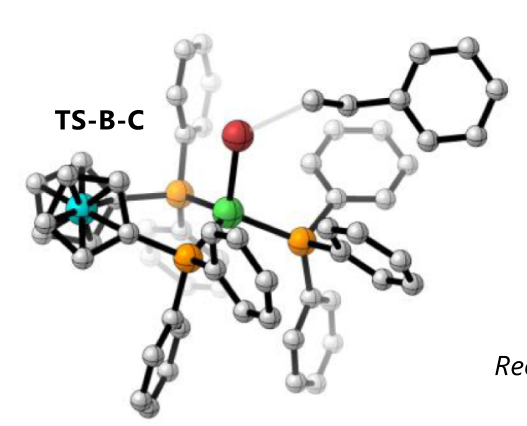
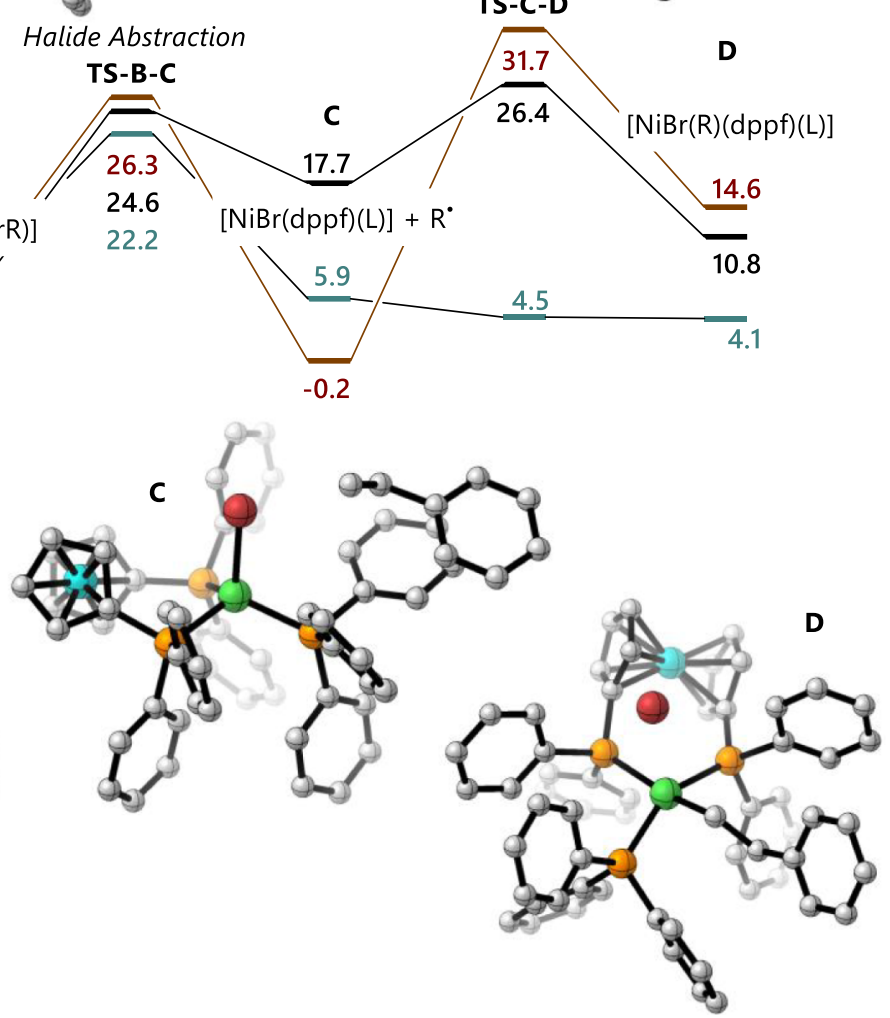

Figure 2. Free energy profiles for the reactions of $[\mathrm{Ni}(\mathrm{COD})(\mathrm{dppf})](\mathbf{1})$ with (2-bromoethyl)benzene (4-Br) in the presence of triphenylphosphine (black), trimethylphosphine (teal), or tricyclohexylphosphine (red). Images represent DFT-derived structures of the relevant intermediates with triphenylphosphine as the added ligand ( $\mathrm{Ni}$ green, Fe blue, $\mathrm{P}$ orange, $\mathrm{Br}$ red, and $\mathrm{C}$ gray) with $\mathrm{H}$ atoms omitted for clarity.

\section{Scheme 4. Model Kumada-Tamao-Corriu Reactions}

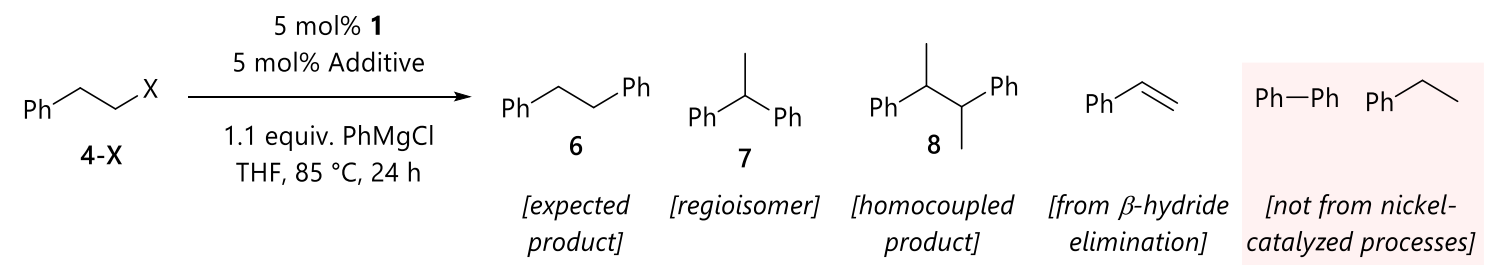

during halide abstraction (D) faces a smaller barrier to re-form the $\mathrm{C}-\mathrm{Br}$ bond $(26.5 \mathrm{kcal} / \mathrm{mol})$ than to form a $\mathrm{C}-\mathrm{Ni}$ bond (31.9 $\mathrm{kcal} / \mathrm{mol})$, and so the halide abstraction is reversible.

The reaction in which triphenylphosphine is present faces neither of these issues. The coordination of a second phosphine ( $\Delta G=3.9 \mathrm{kcal} / \mathrm{mol}$ ) is less favorable than coordination of the substrate $(\Delta G=1.1 \mathrm{kcal} / \mathrm{mol})$ and the transition states for $\mathrm{C}-$ $\mathrm{Br}$ formation and $\mathrm{C}-\mathrm{Ni}$ formation are close in energy $\left(G_{\mathrm{rel}}=\right.$ 24.6 and $26.4 \mathrm{kcal} / \mathrm{mol}$ ), respectively.
The "ideal" added ligand for this process is therefore a ligand that coordinates only once but is not sufficiently bulky to interfere with the recombination of the radical with nickel(I).

Relevance to Catalysis. We sought to link our new understanding of the effects of ligands on the halide abstraction step to the outcomes of catalytic reactions of importance to synthetic chemistry. A series of prototypical Kumada-TamaoCorriu cross-coupling reactions were carried out using (2haloethyl)benzene substrates (4-Cl, 4-Br, 4-I) to understand the effects of additives on catalytic reactions (Scheme 4). All reactions were catalyzed by $5 \mathrm{~mol} \%[\mathrm{Ni}(\mathrm{COD})(\mathrm{dppf})]$ in the 


(a)
None
dppf
$\mathrm{PPh}_{3}$
$\mathrm{FcPPh}_{2}$
$\mathrm{P}\left(o-\mathrm{MeC}_{6} \mathrm{H}_{4}\right)_{3}$
$\mathrm{P}\left(m-\mathrm{MeC}_{6} \mathrm{H}_{4}\right)_{3}$
$\mathrm{P}\left(p-\mathrm{MeC}_{6} \mathrm{H}_{4}\right)_{3}$
$\mathrm{P}\left(o-\mathrm{OMeC}_{6} \mathrm{H}_{4}\right)_{3}$
$\mathrm{P}\left(\mathrm{p}-\mathrm{F}_{3} \mathrm{CC}_{6} \mathrm{H}_{4}\right)_{3}$
$\mathrm{P}\left(\mathrm{p}-\mathrm{FC}_{6} \mathrm{H}_{4}\right)_{3}$
$\mathrm{PMe} \mathrm{H}_{3}$
$\mathrm{P}\left(n-\mathrm{Bu}_{3}\right.$
$\mathrm{PCy}$
$\mathrm{P}(\mathrm{OPh})_{3}$
$\mathrm{AsPh}_{3}$
$\mathrm{SbPh}_{3}$
$\mathrm{NEt}$

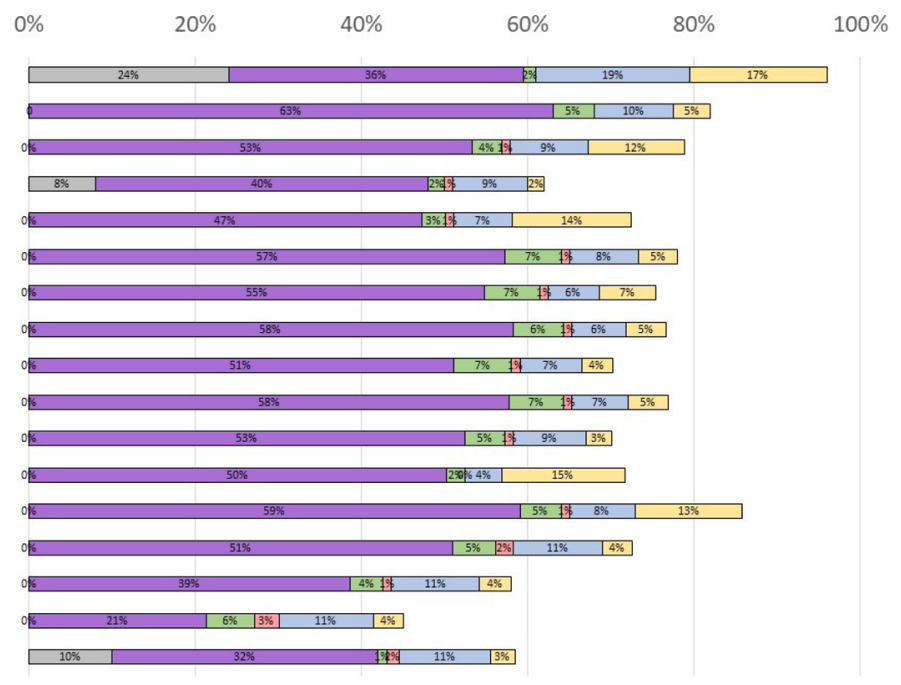

(b)

$\square 4-I \quad \square 6 \quad \square 8 \square$ Styrene $\square$ Ethylbenzene

None

dppf

$\mathrm{PPh}_{3}$

$\mathrm{FCPPh}_{2}$

$\mathrm{P}\left(\mathrm{o}-\mathrm{MeC}_{6} \mathrm{H}_{4}\right)_{3}$

$\mathrm{P}\left(m-\mathrm{MeC}_{6} \mathrm{H}_{4}\right)_{3}$

$\mathrm{P}\left(p-\mathrm{MeC}_{6} \mathrm{H}_{4}\right)_{3}$

$\mathrm{P}\left(\mathrm{o}-\mathrm{OMeC}_{6} \mathrm{H}_{4}\right)_{3}$

$\mathrm{P}\left(\mathrm{p}-\mathrm{F}_{3} \mathrm{CC}_{6} \mathrm{H}_{4}\right)_{3}$

$\mathrm{P}\left(\mathrm{p}-\mathrm{FC}_{6} \mathrm{H}_{4}\right)_{3}$

$\mathrm{PMe}_{3}$

$\mathrm{P}(n-\mathrm{Bu})_{3}$

$\mathrm{PCy}_{3}$

$\mathrm{P}(\mathrm{OPh})_{3}$

$\mathrm{AsPh}_{3}$

$\mathrm{SbPh}_{3}$

$\mathrm{NEt}_{3}$

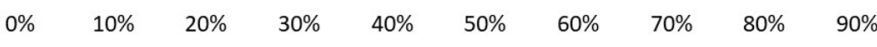

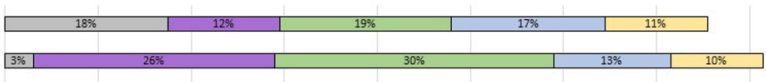

\begin{tabular}{|l|l|l|l|l|l|}
\hline $15 \%$ & $32 \%$ & $5 \%$ & $3 \%$ \\
\hline
\end{tabular}

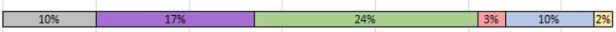

\begin{tabular}{|l|l|l|l|l|}
\hline & & & \\
\hline
\end{tabular}
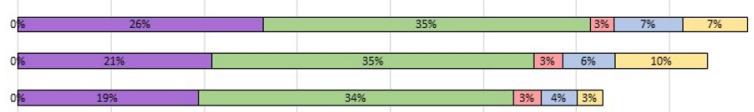

\begin{tabular}{|l|l|l|l|l|l|}
\hline $4 \%$ & $18 \%$ & $25 \%$ & $4 \%$ & $5 \%$ & $10 \%$ \\
\hline
\end{tabular}
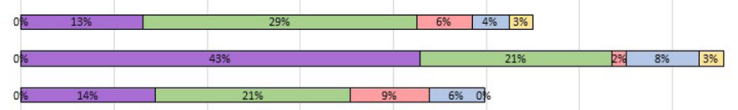

\begin{tabular}{|l|l|l|l|l|}
\hline $11 \%$ & $12 \%$ & $19 \%$ & $5 \%$ & $396 \% 3 \%$ \\
\hline
\end{tabular}
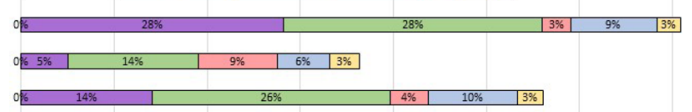

\begin{tabular}{|l|l|l|l|l|l|}
\hline & & & & & \\
\hline
\end{tabular}

$\square 4-\mathrm{Br} \square 6 \square 7 \quad \square 8 \quad \square$ Styrene $\square$ Ethylbenzene

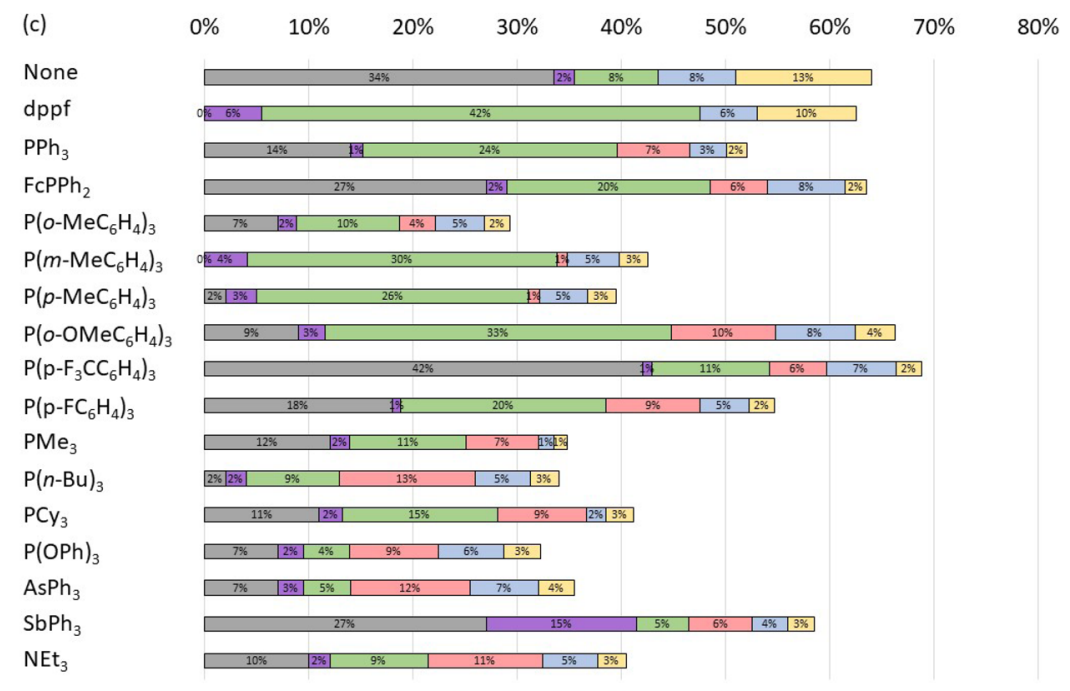

$\square 4-\mathrm{Cl} \square 6 \quad \square 7 \quad \square 8 \quad \square$ Styrene $\square$ Ethylbenzene

Figure 3. Product distributions in model Kumada-Tamao-Corriu cross-coupling reactions using different added ligands. Reactions were conducted with three substrates: (a) (2-iodoethyl)benzene, (b) (2-bromoethyl)benzene, and (c) (2-chloroethyl)benzene.

presence of $5 \mathrm{~mol} \%$ of an additional ligand; the same conditions were used in our previous study. ${ }^{20}$
These reactions, and reactions closely analogous to these, have previously been carried out using other nickel catalysts and 
typically at temperatures around room temperature. Catalyst systems include $10 \mathrm{~mol} \% \mathrm{Cp}^{*} \mathrm{CH}_{2} \mathrm{PPh}_{2} / 5 \mathrm{~mol} \% \mathrm{NiCl}_{2},{ }^{36} 5 \mathrm{~mol}$ $\%$ of a nickel pincer complex, ${ }^{37} 2.5 \mathrm{~mol} \%$ of a dinickel(II)/ tridenate nitrogen ligand complex, ${ }^{38}$ and $2 \mathrm{~mol} \%$ of a diphosphinodithio complex of nickel. ${ }^{39}$ The topics of nickelcatalyzed alkyl halide cross-coupling reactions ${ }^{40,41}$ and nickelcatalyzed Kumada-Tamao-Corriu reactions have been reviewed. $^{42}$

The reactions undertaken for this study, like those disclosed previously, ${ }^{20}$ produced the expected 1,2-diphenylethane product (6), the 1,1-diphenylethane regioisomer (7), styrene, ethylbenzene, and biphenyl (Figure 3). We have shown previously, through the use of control reactions, that ethylbenzene and biphenyl do not arise from nickel-catalyzed reactions. ${ }^{20}$ The regioisomer is likely formed from $\beta$-hydride elimination followed by migratory insertion to generate $[\mathrm{NiX}(\mathrm{CH}(\mathrm{Me}) \mathrm{Ph})(\mathrm{dppf})] .^{20}$ The alkyl halide homocoupling product 2,3-diphenylbutane (8) was observed in some reactions, particularly when $\mathbf{4 - C l}$ was used as the substrate. All reaction outcomes were quantified using gas chromatography-flame ionization detection (GC-FID) analysis with an internal standard; the gas chromatography-flame ionization detector was calibrated using authentic pure samples of each analyte. These model reactions proceed poorly in the absence of an added ligand. The reactions of 4-I are relatively insensitive to the choice of the added ligand, although triphenylstibene and triethylamine perform quite poorly. It is likely that the relatively weak carbon-iodine bond strength means that the halide abstraction step is unlikely to be rate-determining in the reactions of alkyl iodides. These reactions significantly favor the expected (linear) product (6) over the branched side-product (7). The reactions of $4-\mathbf{B r}$ show more diverse outcomes and produce mixtures of 6 and 7 . Here, the most effective ligands appear to be trimethylphosphine, tri(meta-tolyl)phosphine, and triphenylphosphite. The reactions of $\mathbf{4 - C l}$ are evidently more challenging, and most reactions had rather poor mass balance and/or did not achieve complete substrate conversion. Once again, tri(meta-tolyl)phosphine appears to be the best ligand in terms of enabling complete conversion of the alkyl halide substrate, although the major product is regioisomer 7 .

Despite the 200-fold spread of reaction rates in the stoichiometric halide abstraction reactions, the outcomes of catalysis are generally rather less variable. This suggests that the halide abstraction step is not rate-determining within the overall catalytic cycle and/or that the more forcing conditions used for catalysis mitigate the energetic barrier involved for some ligands. Tri(meta-tolyl)phosphine emerges as a ligand that is a good choice for the reactions of any of the three of these substrates. It must be noted that a full optimization of this reaction has not been carried out, but the choice of the added ligand represents an important factor that should be considered in these reactions. This added ligand can of course affect steps other than halide abstraction, but an examination of the full catalytic cycle for this reaction is beyond the scope of the present study.

\section{CONCLUSIONS}

This study has established that a range of different added ligands increase the rate of the reaction between $[\mathrm{Ni}(\mathrm{COD})(\mathrm{dppf})](\mathbf{1})$ and a model alkyl bromide (4-Br), with a ca. 200 -fold range of rate constants. This is consistent with our current mechanistic model which requires a three-coordinate nickel $(0)$ complex that can abstract the halide atom from the alkyl halide substrate. DFT studies have provided further insight into the reaction, identifying that the rate-determining step in the stoichiometric reactions between $\mathbf{1}$ and $4-\mathbf{B r}$ can be either the halide abstraction step or the recombination of the alkyl radical with the nickel(I) complex formed during halide abstraction.

Studies of a prototypical Kumada-Tamao-Corriu reaction have established that the choice of ligand has relatively little effect for the reactions of 4-I but that the reactions in the absence of an added ligand give poor outcomes. The outcomes of the reactions of $4-\mathbf{B r}$ and $4-\mathbf{C l}$ show a more complicated dependence on the structure of the added ligand, but this certainly presents a useful vector for the optimization of these types of cross-coupling reactions.

Further studies of the complex reactions between nickel(0) and alkyl halides and of the related catalytic cross-coupling reactions are currently underway within our laboratories.

The raw data underpinning the experimental parts of this study can be downloaded from the University of Strathclyde Knowledgebase at http://dx.doi.org/10.15129/10523ca42c98-4d77-8575-06d97ba66621. Computational chemistry data underpinning this study can be accessed via the ioChemBD data repository ${ }^{43}$ at http://dx.doi.org/10.19061/iochembd-1-208.

\section{EXPERIMENTAL SECTION}

Materials. Anhydrous toluene, THF, and hexane were obtained from an Inert Technologies PureSolv apparatus $(<10 \mathrm{ppm}$ water by Karl-Fischer titration). Any manipulations of air-sensitive nickel complexes were carried out under argon using Schlenk techniques or in a glovebox. Substrates used for kinetic experiments and crosscoupling reactions were obtained from commercial sources and used as supplied. The synthesis of $\mathrm{FcPPh}_{2}$ and some of the reaction side products are detailed below; characterization data for the remaining products can be found in our previous paper. ${ }^{20}\left[\mathrm{Ni}(\mathrm{COD})_{2}\right](96 \%$ purity) was purchased from Alfa Aesar and stored at $-35{ }^{\circ} \mathrm{C}$ in a glovebox freezer. 1,1'-Bis(diphenylphosphino)ferrocene was purchased from Fluorochem and stored in a glovebox. [Ni(COD)(dppf)] was prepared according to the literature method. ${ }^{19}$ Deuterated solvents were obtained from commercial sources and dried overnight on $4 \AA$ molecular sieves before use.

Analysis. NMR spectroscopy was performed using Bruker AV3400 (liquid nitrogen cryoprobe), Bruker AV3-400 Nano (BBFO-zATMA probe), or Bruker AVII-600 (BBO-z-ATMA) instruments. All kinetic experiments were performed using the latter instrument. ${ }^{1} \mathrm{H}$ NMR spectra are referenced to residual solvent signals, ${ }^{13} \mathrm{C}\left\{{ }^{1} \mathrm{H}\right\}$ NMR spectra are referenced to the deuterated solvent signal, and ${ }^{31} \mathrm{P}\left\{{ }^{1} \mathrm{H}\right\}$ NMR spectra are externally referenced. ${ }^{44}$ Chemical shifts are given in ppm and coupling constants in Hertz. Gas chromatography-mass spectrometry (GC-MS) analyses were carried out using an Agilent 7890A gas chromatograph fitted with a RESTEK-RXi-5Sil column (30 $\mathrm{m} \times 0.32 \mathrm{~mm}$ I.D. $\times 0.25 \mu \mathrm{m})$ connected to an Agilent 5975C MSD running in an EI mode. GC-FID analyses were carried out using an Agilent 7890A gas chromatograph fitted with an Agilent HP5 column $(30 \mathrm{~m} \times 0.25 \mathrm{~mm}$ I.D. $\times 0.25 \mu \mathrm{m})$.

1,4-Diphenylbutane. 1,4-Diphenyl-1,3-butadiene ( $1 \mathrm{~g}, 4.8 \mathrm{mmol})$ was added to a flask with $\mathrm{Pd} / \mathrm{C}(0.1 \mathrm{~g}, 10 \mathrm{wt} \%)$, which was then sealed with a septum and evacuated and backfilled with nitrogen. Propan-2-ol $(20 \mathrm{~mL})$ was added and the flask was evacuated and backfilled again. A balloon of hydrogen was attached to the flask via a needle. The reaction was stirred at room temperature for $24 \mathrm{~h}$. The balloon was removed, the $\mathrm{Pd} / \mathrm{C}$ was filtered off, and the solvent was removed under reduced pressure to give 1,3-diphenylbutane as a white solid $(0.7 \mathrm{~g}, 73 \%) .{ }^{1} \mathrm{H}$ $\operatorname{NMR}\left(400 \mathrm{MHz}^{\mathrm{CDCl}} \mathrm{CD}_{3}\right): \delta 1.71\left(\mathrm{~d} t, 4 \mathrm{H}, \mathrm{J}_{\mathrm{H}-\mathrm{H}}=7.0, \mathrm{ArCH}_{2}\right), 2.67(t$, $\left.4 \mathrm{H}^{3} \mathrm{~J}_{\mathrm{H}-\mathrm{H}}=7.1, \mathrm{ArCH}_{2} \mathrm{CH}_{2}\right), 7.19-7.22(m, 6 \mathrm{H}$, aryl C-H $), 7.28-$ $7.32\left(m, 4 \mathrm{H}\right.$, aryl C-H). ${ }^{13} \mathrm{C}\left\{{ }^{1} \mathrm{H}\right\}$ NMR $\left(101 \mathrm{MHz} \mathrm{CDCl}_{3}\right): \delta 30.6$, 35.3, 125.1, 127.8, 127.9, 142.2. GC-MS $\left(\mathrm{C}_{16} \mathrm{H}_{18}\right) \mathrm{m} / z$ : 210.2. NMR data are consistent with the literature. ${ }^{45}$ 
2,3-Diphenylbutane. Benzil (2 g, $9.5 \mathrm{mmol}$ ) was dissolved in anhydrous THF $(20 \mathrm{~mL})$ under a nitrogen atmosphere. $\mathrm{MeMgCl}(12.6$ $\mathrm{mL}, 3 \mathrm{M}$ in THF, $37.8 \mathrm{mmol}$ ) was added dropwise and the mixture was stirred at room temperature for $16 \mathrm{~h}$. The reaction mixture was quenched $(\mathrm{HCl}, 1 \mathrm{M}, 100 \mathrm{~mL})$ and extracted with $\mathrm{DCM}(3 \times 20 \mathrm{~mL})$. The organic layers were combined, dried over $\mathrm{MgSO}_{4}$, filtered, and concentrated to give 2,3-diphenylbutane-2,3-diol which was used in the next step without purification. Following a literature preparation, ${ }^{46} 2,3$ diphenylbutane-2,3-diol (1.5 g) was dissolved in hexamethylphosphoramide $(20 \mathrm{~mL})$ and stirred at room temperature for $2 \mathrm{~h}$. The mixture was then heated to reflux for $90 \mathrm{~min}$. After cooling, $\mathrm{Et}_{2} \mathrm{O}(25 \mathrm{~mL})$ was added and the reaction mixture was washed with water $(100 \mathrm{~mL})$. The aqueous layer was extracted with $\mathrm{Et}_{2} \mathrm{O}(15 \mathrm{~mL})$. The combined organic layers were then washed with water $(2 \times 50 \mathrm{~mL})$ and brine $(25 \mathrm{~mL})$, dried over $\mathrm{MgSO}_{4}$, filtered, and concentrated to give brown/red oil. Column chromatography on silica gel (petroleum ether) gave 2,3diphenylbuta-1,3-diene as a white solid. 2,3-Diphenylbuta-1,3-diene $(150 \mathrm{mg}$ ) was added to a RBF with Pd/C (15 mg, 10 wt \%), which was then sealed with a septum and evacuated and backfilled with nitrogen. Propan-2-ol $(20 \mathrm{~mL})$ was added and the flask was evacuated and backfilled again. A balloon of hydrogen was attached to the flask via a needle. The reaction was then stirred at room temperature for $24 \mathrm{~h}$. The balloon was removed, the $\mathrm{Pd} / \mathrm{C}$ was filtered off and the solvent was removed under reduced pressure to give 2,3-diphenylbutane $(95 \mathrm{mg}$, $5 \%$ over three steps) as a white solid. ${ }^{1} \mathrm{H}$ NMR $\left(400 \mathrm{MHz}, \mathrm{CDCl}_{3}\right): \delta$ $1.05\left(\mathrm{dd}, 6 \mathrm{H},{ }^{3} J_{\mathrm{H}-\mathrm{H}}=2.2,6.7\right), 1.31\left(\mathrm{dd}, 4 \mathrm{H},{ }^{3} J_{\mathrm{H}-\mathrm{H}}=1.9,6.7\right), 2.80-$ $2.84(m, 2 \mathrm{H}), 2.93-3.00(m, 1.3 \mathrm{H}), 7.02-7.04(m, 2.5 \mathrm{H}), 7.09-7.14$ $(m, 1.3 \mathrm{H}), 7.17-7.26(m, 8.2 \mathrm{H}), 7.32-7.36(m, 3.8 \mathrm{H}) .{ }^{13} \mathrm{C}\left\{{ }^{1} \mathrm{H}\right\} \mathrm{NMR}$ $\left(101 \mathrm{MHz}, \mathrm{CDCl}_{3}\right): \delta 17.4,20.5,45.9,46.8,125.2,125.5,127.1,127.2$, 127.3, 127.8, 145.9. GC-MS $\left(\mathrm{C}_{16} \mathrm{H}_{18}\right) \mathrm{m} / \mathrm{z}: 210.2$. NMR data are consistent with the literature. ${ }^{47}$

Diphenylphosphinoferrocene. This was prepared according to a literature procedure. ${ }^{48}$ Ferrocene $(1.9 \mathrm{~g}, 0.1 \mathrm{mmol})$ and aluminum chloride (1.3 g, $0.1 \mathrm{mmol})$ were dissolved in hexane $(20 \mathrm{~mL})$. Chlorodiphenylphosphine was added and the solution was heated at reflux for $16 \mathrm{~h}$. The hexane was decanted and solids were extracted with fresh hexane $(50 \mathrm{~mL})$. This was repeated with water $(50 \mathrm{~mL})$. The hexane and water were discarded, and the remaining solids were extracted with hot toluene $(50 \mathrm{~mL})$. The toluene was dried over $\mathrm{MgSO}_{4}$, filtered, and concentrated to dryness. The residue was extracted with hexane $(100 \mathrm{~mL})$ and this was concentrated to yield the product as yellow powder (92 mg, 3\%). ${ }^{1} \mathrm{H}$ NMR $(400 \mathrm{MHz}$, $\left.\mathrm{CDCl}_{3}\right): \delta 4.12\left(\mathrm{q}, 4 \mathrm{H},{ }^{3} J_{\mathrm{H}-\mathrm{H}}=1.8 \mathrm{~Hz}\right), 4.39\left(t, 4 \mathrm{H},{ }^{3} J_{\mathrm{H}-\mathrm{H}}=1.8 \mathrm{~Hz}\right)$, 7.33-7.41 (m, 20H). ${ }^{13} \mathrm{C}\left\{{ }^{1} \mathrm{H}\right\} \operatorname{NMR}\left(101 \mathrm{MHz}, \mathrm{CDCl}_{3}\right): \delta 68.6,70.2$ $\left(\mathrm{d}, J_{\mathrm{P}-\mathrm{C}}=3.9\right), 72.4\left(\mathrm{~d}, J_{\mathrm{P}-\mathrm{C}}=14.9\right), 127.6\left(\mathrm{~d}, J_{\mathrm{P}-\mathrm{C}}=14.9\right), 127.9$, $132.9,133.1,138.6\left(\mathrm{~d}, J_{\mathrm{P}-\mathrm{C}}=9.6\right) .{ }^{31} \mathrm{P}\left\{{ }^{1} \mathrm{H}\right\} \operatorname{NMR}\left(162 \mathrm{MHz}, \mathrm{CDCl}_{3}\right)$ : $\delta-17.0$.

Kinetic Experiments. Kinetic data were obtained using the same methodology that has been deployed previously, by monitoring the decay of the concentration of $[\mathrm{Ni}(\mathrm{COD})(\mathrm{dppf})]$ over time by ${ }^{31} \mathrm{P}$ or ${ }^{31} \mathrm{P}\left\{{ }^{1} \mathrm{H}\right\}$ NMR spectroscopy. ${ }^{13,20,28}$ For a typical experiment, in an argon-filled glovebox, a septum-fitted NMR tube was charged with a benzene- $d_{6}$ or toluene- $d_{8}$ solution containing $[\mathrm{Ni}(\mathrm{COD})(\mathrm{dppf})](8$ $\mathrm{mg}, 0.011 \mathrm{mmol}$ ) and any solid additives. Any liquid additives-or stock solutions of additives-were then added. The total volume of the reaction was $0.5 \mathrm{~mL}$ This sample was used to tune, match, lock, and shim the spectrometer. The alkyl halide was then added via a syringe through the septum to start the reaction, and ${ }^{31} \mathrm{P}\left\{{ }^{1} \mathrm{H}\right\}$ NMR spectra were acquired at intervals until ca. $87 \%$ conversion (16 scans, $2 \mathrm{~s}$ between scans). All experiments were performed in duplicate. In all reactions, pseudo-first-order rate constants $\left(k_{\text {obs }}\right)$ were obtained from a linear plot of the natural $\log$ of the integral of the signal for $[\mathrm{Ni}(\mathrm{COD})(\mathrm{dppf})]$ versus time. The rate constants from each experiment are tabulated in the Supporting Information.

Cross-Coupling Reactions. In an argon-filled glovebox, [Ni(COD)(dppf)] (0.0125 mmol, $5 \mathrm{~mol} \%)$ and any solid additives were added to a microwave vial equipped with a stirrer bar. The vial was sealed with a septum-fitted cap and removed from the glovebox. On a Schlenk line, anhydrous THF $(1 \mathrm{~mL})$ was added followed by phenylmagnesium chloride $(0.28 \mathrm{mmol}, 1.1$ equiv). The vial was then heated (with rapid stirring) to $85^{\circ} \mathrm{C}$. When at the desired temperature, any liquid additives and the aryl halide $(0.25 \mathrm{mmol})$ were added via a microsyringe. The reactions were stirred at $85^{\circ} \mathrm{C}$ for $24 \mathrm{~h}$, then cooled to room temperature, and pierced with a needle. Each vial was opened, an accurately known amount of $n$-tetradecane was added, and a sample was taken for GC-FID analysis. All reactions were performed in duplicate; average conversions are reported in the paper, and the result of each individual cross-coupling reaction is tabulated in the Supporting Information. The gas chromatography-flame ionization detector was calibrated for each substrate and product using authentic samples of each compound.

Computational Methodology. DFT calculations were carried out using Gaussian16 Rev. A.03. ${ }^{49}$ DLPNO-CCSD $(\mathrm{T})$ calculations ${ }^{50-52}$ were carried out using Orca 4.2.1. ${ }^{53,54}$ Geometry optimizations were carried out without symmetry constraints using the B3LYP functional ${ }^{55-58}$ with the Grimme D3 empirical dispersion correction. ${ }^{59}$ The LANL2TZ(f) pseudopotential/ECP was used for nickel and iron, while LANL2DZ $(\mathrm{d}, \mathrm{p})$ was used for bromine, arsenic, and antimony. ${ }^{60-62}$ The $6-31 G(d)$ basis set was used for all other atoms. Frequency calculations verified the nature of stationary points. Transition states were checked using IRC calculations or by optimizing structures along the reaction coordinate. The energies of all structures were refined using single point calculations with the M06 functional, ${ }^{63}$ the LANL2DZ $(\mathrm{d}, \mathrm{p})$ pseudopotential/ECP on antimony, and the 6-311+ $\mathrm{G}(\mathrm{d}, \mathrm{p})$ basis set on all other atoms. Solvation was included for the single point calculations using the SMD model (in benzene) ${ }^{64}$ This level of theory was decided upon by benchmarking calculations for the formation of $\left[\mathrm{Ni}(\mathrm{dppf})_{2}\right]$ plus COD from $[\mathrm{Ni}(\mathrm{COD})(\mathrm{dppf})]$ plus dppf: $\Delta G$ (experiment $)=-1.2 \mathrm{kcal} / \mathrm{mol} ; \Delta G(\mathrm{DLPNO}-\mathrm{CCSD}(\mathrm{T}) / \mathrm{cc}-$ $\mathrm{pVTZ})=-1.6 \mathrm{kcal} / \mathrm{mol} ; \Delta G(\mathrm{M} 06 / 6-311+G(\mathrm{~d}, \mathrm{p})=-1.5 \mathrm{kcal} / \mathrm{mol}$ (see the Supporting Information for full details). A correction of +1.89 $\mathrm{kcal} / \mathrm{mol}$ was applied to the free energy of each species to consider a 1 $\mathrm{mol} / \mathrm{L}$ reference state for the calculations rather than the ideal gas concentration. ${ }^{65}$ Yamaguchi's approach was used to correct the electronic energies of open shell singlets for triplet contamination. ${ }^{66}$ The images of DFT-derived structures in Figure 2 were prepared using CYLView 2.0. ${ }^{67}$

\section{ASSOCIATED CONTENT}

\section{(s) Supporting Information}

The Supporting Information is available free of charge at https://pubs.acs.org/doi/10.1021/acs.organomet.1c00280.

Kinetic data, computational data (methods and energies), and data regarding the outcomes of catalytic reactions (PDF)

Coordinates of the structures modeled using DFT calculations (XYZ)

\section{AUTHOR INFORMATION}

\section{Corresponding Author}

David J. Nelson - WestCHEM Department of Pure and Applied Chemistry, University of Strathclyde, Glasgow G1 1XL, Scotland; (1) orcid.org/0000-0002-9461-5182; Email: david.nelson@strath.ac.uk

\section{Authors}

Megan E. Greaves - WestCHEM Department of Pure and Applied Chemistry, University of Strathclyde, Glasgow G1 1XL, Scotland; Chemical Development, Pharmaceutical Technology and Development, Operations, AstraZeneca, Macclesfield SK10 2NA, U.K.; (1) orcid.org/0000-00016506-9541

Thomas O. Ronson - Chemical Development, Pharmaceutical Technology and Development, Operations, AstraZeneca, Macclesfield SK10 2NA, U.K.; (1) orcid.org/0000-00017864-7275 
Feliu Maseras - Institute of Chemical Research of Catalonia (ICIQ), The Barcelona Institute of Science and Technology, Tarragona 43007, Spain; ๑ orcid.org/0000-0001-88062019

Complete contact information is available at:

https://pubs.acs.org/10.1021/acs.organomet.1c00280

\section{Author Contributions}

The manuscript was written through contributions of all authors.

\section{Funding}

We thank AstraZeneca and the Engineering and Physical Sciences Research Council (EPSRC) for an Industrial CASE Studentship for MEG (EP/R512114/1). D.J.N. thanks the University of Strathclyde for a Chancellor's Fellowship (201418).

\section{Notes}

The authors declare no competing financial interest.

\section{ACKNOWLEDGMENTS}

Some of the calculations in this manuscript were conducted using the Archie-WEST high-performance computer hosted at the University of Strathclyde; we are grateful to Mr. J. Buzzard, Dr. K. Kubiak-Ossowska, and Dr. R. Martin for their assistance with this facility. We thank Mr. F. McGeoch, Mr. C. Irving, Ms. P. Keating, and Dr. J. Parkinson for their assistance with technical and analytical facilities within the Department of Pure and Applied Chemistry at the University of Strathclyde.

\section{ABBREVIATIONS}

DPPF $1,1^{\prime}$-bis(diphenylphosphino)ferrocene;

SIMes 1,3-bis(2,4,6-trimethylphenyl)-4,5-dihydroimidazol-2ylidene

NHC N-heterocyclic carbene

\section{REFERENCES}

(1) Lovering, F.; Bikker, J.; Humblet, C. Escape from Flatland: Increasing Saturation as an Approach to Improving Clinical Success. J. Med. Chem. 2009, 52, 6752-6756.

(2) Lovering, F. Escape from Flatland 2: complexity and promiscuity. MedChemComm 2013, 4, 515-519.

(3) Diccianni, J.; Lin, Q.; Diao, T. Mechanisms of Nickel-Catalyzed Coupling Reactions and Applications in Alkene Functionalization. Acc. Chem. Res. 2020, 53, 906-919.

(4) Weix, D. J. Methods and Mechanisms for Cross-Electrophile Coupling of Csp2 Halides with Alkyl Electrophiles. Acc. Chem. Res. 2015, 48, 1767-1775.

(5) Greaves, M. E.; Johnson Humphrey, E. L. B.; Nelson, D. J. Reactions of nickel $(0)$ with organochlorides, organobromides, and organoiodides: mechanisms and structure/reactivity relationships. Catal. Sci. Technol. 2021, 11, 2980-2996.

(6) Liu, R. Y.; Dennis, J. M.; Buchwald, S. L. The Quest for the Ideal Base: Rational Design of a Nickel Precatalyst Enables Mild, Homogeneous C-N Cross-Coupling. J. Am. Chem. Soc. 2020, 142, $4500-4507$.

(7) Zhang, S.-Q.; Taylor, B. L. H.; Ji, C.-L.; Gao, Y.; Harris, M. R.; Hanna, L. E.; Jarvo, E. R.; Houk, K. N.; Hong, X. Mechanism and Origins of Ligand-Controlled Stereoselectivity of Ni-Catalyzed Suzuki-Miyaura Coupling with Benzylic Esters: A Computational Study. J. Am. Chem. Soc. 2017, 139, 12994-13005.

(8) Zhang, K.; Conda-Sheridan, M.; Cooke, S. R.; Louie, J. NHeterocyclic Carbene Bound Nickel(I) Complexes and Their Roles in Catalysis. Organometallics 2011, 30, 2546-2552.
(9) Nelson, D. J.; Maseras, F. Steric effects determine the mechanisms of reactions between bis( $\mathrm{N}$-heterocyclic carbene)-nickel(0) complexes and aryl halides. Chem. Commun. 2018, 54, 10646-10649.

(10) Kalvet, I.; Guo, Q.; Tizzard, G. J.; Schoenebeck, F. When Weaker Can Be Tougher: The Role of Oxidation State (I) in P- vs N-LigandDerived Ni-Catalyzed Trifluoromethylthiolation of Aryl Halides. ACS Catal. 2017, 7, 2126-2132.

(11) Hong, X.; Liang, Y.; Houk, K. N. Mechanisms and Origins of Switchable Chemoselectivity of Ni-Catalyzed $\mathrm{C}(\operatorname{aryl})-\mathrm{O}$ and $\mathrm{C}$ (acyl)-O Activation of Aryl Esters with Phosphine Ligands. J. Am. Chem. Soc. 2014, 136, 2017-2025.

(12) Entz, E. D.; Russell, J. E. A.; Hooker, L. V.; Neufeldt, S. R. Small Phosphine Ligands Enable Selective Oxidative Addition of Ar-O over Ar-Cl Bonds at $\operatorname{Nickel}(0)$. J. Am. Chem. Soc. 2020, 142, 15454-15463.

(13) Bajo, S.; Laidlaw, G.; Kennedy, A. R.; Sproules, S.; Nelson, D. J. Oxidative Addition of Aryl Electrophiles to a Prototypical Nickel(0) Complex: Mechanism and Structure/Reactivity Relationships. Organometallics 2017, 36, 1662-1672.

(14) Manzoor, A.; Wienefeld, P.; Baird, M. C.; Budzelaar, P. H. M. Catalysis of Cross-Coupling and Homocoupling Reactions of Aryl Halides Utilizing $\mathrm{Ni}(0), \mathrm{Ni}(\mathrm{I})$, and $\mathrm{Ni}(\mathrm{II})$ Precursors; $\mathrm{Ni}(0)$ Compounds as the Probable Catalytic Species but Ni(I) Compounds as Intermediates and Products. Organometallics 2017, 36, 3508-3519.

(15) Tsou, T. T.; Kochi, J. K. Mechanism of oxidative addition. Reaction of nickel(0) complexes with aromatic halides. J. Am. Chem. Soc. 1979, 101, 6319-6332.

(16) Pérez-García, P. M.; Darù, A.; Scheerder, A. R.; Lutz, M.; Harvey, J. N.; Moret, M.-E. Oxidative Addition of Aryl Halides to a Triphosphine $\mathrm{Ni}(0)$ Center to Form Pentacoordinate Ni(II) Aryl Species. Organometallics 2020, 39, 1139-1144.

(17) Pérez-García, P. M.; Moret, M.-E. Mechanistic Studies of the Oxidative Addition of Aryl Halides to $\mathrm{Ni}(0)$ Centers Bearing Phosphine Ligands. CHIMIA International Journal for Chemistry 2020, 74, 495-498.

(18) Kehoe, R.; Mahadevan, M.; Manzoor, A.; McMurray, G.; Wienefeld, P.; Baird, M. C.; Budzelaar, P. H. M. Reactions of the Ni(0) Compound $\mathrm{Ni}(\mathrm{PPh} 3) 4$ with Unactivated Alkyl Halides: Oxidative Addition Reactions Involving Radical Processes and Nickel(I) Intermediates. Organometallics 2018, 37, 2450-2467.

(19) Yin, G.; Kalvet, I.; Englert, U.; Schoenebeck, F. Fundamental Studies and Development of Nickel-Catalyzed Trifluoromethylthiolation of Aryl Chlorides: Active Catalytic Species and Key Roles of Ligand and Traceless MeCN Additive Revealed. J. Am. Chem. Soc. 2015, 137, $4164-4172$.

(20) Greaves, M. E.; Ronson, T. O.; Lloyd-Jones, G. C.; Maseras, F.; Sproules, S.; Nelson, D. J. Unexpected Nickel Complex Speciation Unlocks Alternative Pathways for the Reactions of Alkyl Halides with dppf-Nickel(0). ACS Catal. 2020, 10, 10717-10725.

(21) Tolman, C. A. Steric effects of phosphorus ligands in organometallic chemistry and homogeneous catalysis. Chem. Rev. 1977, 77, 313-348.

(22) Hansch, C.; Leo, A.; Taft, R. W. A survey of Hammett substituent constants and resonance and field parameters. Chem. Rev. 1991, 91, $165-195$.

(23) We note that triphenylphosphine lies quite far off the line of best fit in each case. These reactions were repeated with freshly recrystallized triphenylphosphine but this did not affect the reaction rate.

(24) All six ligands are plotted on the graph, but $p$-F and $m$-Me have the same substituent constant and so these are superimposed.

(25) Funes-Ardoiz, I.; Nelson, D. J.; Maseras, F. Halide Abstraction Competes with Oxidative Addition in the Reactions of Aryl Halides with $[\mathrm{Ni}(\mathrm{PMenPh}(3-\mathrm{n})) 4]$. Chem. - Eur. J. 2017, 23, 16728-16733.

(26) Desnoyer, A. N.; He, W.; Behyan, S.; Chiu, W.; Love, J. A.; Kennepohl, P. The Importance of Ligand-Induced Backdonation in the Stabilization of Square Planar d(10) Nickel pi-Complexes. Chemistry 2019, 25, 5259-5268.

(27) He, W.; Kennepohl, P. Direct experimental evaluation of ligandinduced backbonding in nickel metallacyclic complexes. Faraday Discuss. 2019, 220, 133-143. 
(28) Cooper, A. K.; Leonard, D. K.; Bajo, S.; Burton, P. M.; Nelson, D. $\mathrm{J}$. Aldehydes and ketones influence reactivity and selectivity in nickelcatalysed Suzuki-Miyaura reactions. Chem. Sci. 2020, 11, 1905-1911.

(29) Poater, A.; Cosenza, B.; Correa, A.; Giudice, S.; Ragone, F.; Scarano, V.; Cavallo, L. SambVca: A Web Application for the Calculation of the Buried Volume of N-Heterocyclic Carbene Ligands. Eur. J. Inorg. Chem. 2009, 2009, 1759-1766.

(30) Falivene, L.; Credendino, R.; Poater, A.; Petta, A.; Serra, L.; Oliva, R.; Scarano, V.; Cavallo, L. SambVca 2. A Web Tool for Analyzing Catalytic Pockets with Topographic Steric Maps. Organometallics 2016, 35, 2286-2293.

(31) Falivene, L.; Cao, Z.; Petta, A.; Serra, L.; Poater, A.; Oliva, R.; Scarano, V.; Cavallo, L. Towards the online computer-aided design of catalytic pockets. Nat. Chem. 2019, 11, 872-879.

(32) Clavier, H.; Nolan, S. P. Percent buried volume for phosphine and N-heterocyclic carbene ligands: steric properties in organometallic chemistry. Chem. Commun. 2010, 46, 841-861.

(33) Gomez-Suarez, A.; Nelson, D. J.; Nolan, S. P. Quantifying and understanding the steric properties of N-heterocyclic carbenes. Chem. Commun. 2017, 53, 2650-2660.

(34) Liu, N.; Li, X.; Xu, X.; Wang, Z.; Sun, H. Synthesis, structure and DFT study of dinuclear iron, cobalt and nickel complexes with cyclopentadienyl-metal moieties. Dalton Trans. 2011, 40, 6886-6892.

(35) Kampmann, S. S.; Sobolev, A. N.; Koutsantonis, G. A.; Stewart, S. G. Stable Nickel(0) Phosphites as Catalysts for C-N Cross-Coupling Reactions. Adv. Synth. Catal. 2014, 356, 1967-1973.

(36) Uemura, M.; Yorimitsu, H.; Oshima, K. Synthesis of $\mathrm{Cp} * \mathrm{CH} 2 \mathrm{PPh} 2$ and its use as a ligand for the nickel-catalysed crosscoupling reaction of alkyl halides with aryl Grignard reagents. Chem. Commun. 2006, 45, 4726-4728.

(37) Vechorkin, O.; Proust, V.; Hu, X. Functional Group Tolerant Kumada-Corriu-Tamao Coupling of Nonactivated Alkyl Halides with Aryl and Heteroaryl Nucleophiles: Catalysis by a Nickel Pincer Complex Permits the Coupling of Functionalized Grignard Reagents. J. Am. Chem. Soc. 2009, 131, 9756-9766.

(38) Xue, F.; Zhao, J.; Hor, T. S. A. Cross-coupling of alkyl halides with aryl or alkyl Grignards catalyzed by dinuclear $\mathrm{Ni}$ (ii) complexes containing functionalized tripodal amine-pyrazolyl ligands. Dalton Trans. 2013, 42, 5150-5158.

(39) Zhang, A.; Wang, C.; Lai, X.; Zhai, X.; Pang, M.; Tung, C.-H.; Wang, W. Reactivity of the diphosphinodithio ligated nickel(0) complex toward alkyl halides and resultant nickel(i) and nickel(ii)alkyl complexes. Dalton Trans. 2018, 47, 15757-15764.

(40) Netherton, M. R.; Fu, G. C. Nickel-Catalyzed Cross-Couplings of Unactivated Alkyl Halides and Pseudohalides with Organometallic Compounds. Adv. Synth. Catal. 2004, 346, 1525-1532.

(41) $\mathrm{Hu}, \mathrm{X}$. Nickel-catalyzed cross coupling of non-activated alkyl halides: a mechanistic perspective. Chem. Sci. 2011, 2, 1867-1886.

(42) Fache, F.; Pelotier, B.; Piva, O., Grignard Reagents and Transition Metal Catalysts. In 2. Grignard Reagents and Nickel, Janine, C., Ed. De Gruyter: 2016; pp. 61-113.

(43) Álvarez-Moreno, M.; de Graaf, C.; López, N.; Maseras, F.; Poblet, J. M.; Bo, C. Managing the Computational Chemistry Big Data Problem: The ioChem-BD Platform. J. Chem. Inf. Model. 2015, 55, 95103.

(44) Fulmer, G. R.; Miller, A. J. M.; Sherden, N. H.; Gottlieb, H. E.; Nudelman, A.; Stoltz, B. M.; Bercaw, J. E.; Goldberg, K. I. NMR Chemical Shifts of Trace Impurities: Common Laboratory Solvents, Organics, and Gases in Deuterated Solvents Relevant to the Organometallic Chemist. Organometallics 2010, 29, 2176-2179.

(45) Liu, G.-B.; Zhao, H.-Y.; Dai, L.; Thiermann, T.; Tashiro, H.; Tashiro, M. Raney Ni-Al alloy-mediated reduction of benzils in water. J. Chem. Res. 2009, 2009, 579-581.

(46) Wagner, R. A.; Brinker, U. H. A Novel and Facile Synthesis of 2,3Diphenylbuta-1,3-diene. Synthesis 2001, 2001, 0376-0378.

(47) Prinsell, M. R.; Everson, D. A.; Weix, D. J. Nickel-catalyzed, sodium iodide-promoted reductive dimerization of alkyl halides, alkyl pseudohalides, and allylic acetates. Chem. Commun. 2010, 46, 57435745 .
(48) Sollott, G. P.; Mertwoy, H. E.; Portnoy, S.; Snead, J. L. Unsymmetrical Tertiary Phosphines of Ferrocene by Friedel-Crafts Reactions. I. Ferrocenylphenylphosphines. J. Org. Chem. 1963, 28, 1090-1092.

(49) Frisch, M. J.; Trucks, G. W.; Schlegel, H. B.; Scuseria, G. E.; Robb, M. A.; Cheeseman, J. R.; Scalmani, G.; Barone, V.; Petersson, G. A.; Nakatsuji, H.; Li, X.; Caricato, M.; Marenich, A. V.; Bloino, J.; Janesko, B. G.; Gomperts, R.; Mennucci, B.; Hratchian, H. P.; Ortiz, J. V.; Izmaylov, A. F.; Sonnenberg, J. L.; Williams-Young, D.; Ding, F.; Lipparini, F.; Egidi, F.; Goings, J.; Peng, B.; Petrone, A.; Henderson, T.; Ranasinghe, D.; Zakrzewski, V. G.; Gao, J.; Rega, N.; Zheng, G.; Liang, W.; Hada, M.; Ehara, M.; Toyota, K.; Fukuda, R.; Hasegawa, J.; Ishida, M.; Nakajima, T.; Honda, Y.; Kitao, O.; Nakai, H.; Vreven, T.; Throssell, K.; Montgomery, Jr., J. A.; Peralta, J. E.; Ogliaro, F.; Bearpark, M. J.; Heyd, J. J.; Brothers, E. N.; Kudin, K. N.; Staroverov, V. N.; Keith, T. A.; Kobayashi, R.; Normand, J.; Raghavachari, K.; Rendell, A. P.; Burant, J. C.; Iyengar, S. S.; Tomasi, J.; Cossi, M.; Millam, J. M.; Klene, M.; Adamo, C.; Cammi, R.; Ochterski, J. W.; Martin, R. L.; Morokuma, K.; Farkas, O.; Foresman, J. B.; Fox, D. J. Gaussian 16 Rev. A.03, Gaussian, Inc.: Wallingford, CT, 2016.

(50) Riplinger, C.; Neese, F. An efficient and near linear scaling pair natural orbital based local coupled cluster method. J. Chem. Phys. 2013, 138, No. 034106

(51) Riplinger, C.; Pinski, P.; Becker, U.; Valeev, E. F.; Neese, F. Sparse maps-A systematic infrastructure for reduced-scaling electronic structure methods. II. Linear scaling domain based pair natural orbital coupled cluster theory. J. Chem. Phys. 2016, 144, No. 024109.

(52) Riplinger, C.; Sandhoefer, B.; Hansen, A.; Neese, F. Natural triple excitations in local coupled cluster calculations with pair natural orbitals. J. Chem. Phys. 2013, 139, 134101.

(53) Neese, F. The ORCA program system. WIREs Comput. Mol. Sci. 2012, 2, 73-78.

(54) Neese, F. Software update: the ORCA program system, version 4.0. WIREs Comput. Mol. Sci. 2018, 8, No. e1327.

(55) Becke, A. D. Density-functional thermochemistry. III. The role of exact exchange. J. Chem. Phys. 1993, 98, 5648-5652.

(56) Lee, C.; Yang, W.; Parr, R. G. Development of the Colle-Salvetti correlation-energy formula into a functional of the electron density. Phys. Rev. B.: Condens. Mater. 1988, 37, 785-789.

(57) Vosko, S. H.; Wilk, L.; Nusair, M. Accurate spin-dependent electron liquid correlation energies for local spin density calculations: a critical analysis. Can. J. Phys. 1980, 58, 1200-1211.

(58) Stephens, P. J.; Devlin, F. J.; Chabalowski, C. F.; Frisch, M. J. Ab Initio Calculation of Vibrational Absorption and Circular Dichroism Spectra Using Density Functional Force Fields. J. Phys. Chem. 1994, 98, $11623-11627$.

(59) Grimme, S.; Antony, J.; Ehrlich, S.; Krieg, H. A consistent and accurate $\mathrm{ab}$ initio parametrization of density functional dispersion correction (DFT-D) for the 94 elements H-Pu. J. Chem. Phys. 2010, 132, 154104-154119.

(60) Ehlers, A. W.; Böhme, M.; Dapprich, S.; Gobbi, A.; Höllwarth, A.; Jonas, V.; Köhler, K. F.; Stegmann, R.; Veldkamp, A.; Frenking, G. A set of f-polarization functions for pseudo-potential basis sets of the transition metals $\mathrm{Sc}-\mathrm{Cu}, \mathrm{Y}-\mathrm{Ag}$ and $\mathrm{La}-\mathrm{Au}$. Chem. Phys. Lett. 1993, 208, 111-114.

(61) Hay, P. J.; Wadt, W. R. Ab initio effective core potentials for molecular calculations. Potentials for $\mathrm{K}$ to $\mathrm{Au}$ including the outermost core orbitals. J. Chem. Phys. 1985, 82, 299-310.

(62) Roy, L. E.; Hay, P. J.; Martin, R. L. Revised Basis Sets for the LANL Effective Core Potentials. J. Chem. Theor. Comput. 2008, 4, $1029-1031$

(63) Zhao, Y.; Truhlar, D. G. Density Functionals with Broad Applicability in Chemistry. Acc. Chem. Res. 2008, 41, 157-167.

(64) Marenich, A. V.; Cramer, C. J.; Truhlar, D. G. Universal Solvation Model Based on Solute Electron Density and on a Continuum Model of the Solvent Defined by the Bulk Dielectric Constant and Atomic Surface Tensions. J. Phys. Chem. B 2009, 113, 6378-6396. 
(65) Harvey, J. N.; Himo, F.; Maseras, F.; Perrin, L. Scope and Challenge of Computational Methods for Studying Mechanism and Reactivity in Homogeneous Catalysis. ACS Catal. 2019, 9, 6803-6813.

(66) Yamaguchi, K.; Jensen, F.; Dorigo, A.; Houk, K. N. A spin correction procedure for unrestricted Hartree-Fock and Møller-Plesset wavefunctions for singlet diradicals and polyradicals. Chem. Phys. Lett. 1988, 149, 537-542.

(67) Legault, C. Y., CYLview20, Université de Sherbrooke, 2020, http://www.cylview.org. 